4. Hartman J, Tang JE, Wilkinson SB, et al. Consumption of fat-free fluid milk after resistance exercise promotes greater lean mass accretion than does consumption of soy or carbohydrate in young, novice, male weightlifters. Am J Clin Nutr 2007;86:373-381.

5. Josse AR, Tang JE, Tarnopolsky MA, et al. Body composition and strength changes in women with milk and resistance exercise. Med Sci Sports Exerc 2010;42:1122-1130.

6. Kerksick CM, Rasmussen CJ, Lancaster SL, et al. The effects of protein and amino acid supplementation on performance and training adaptations during ten weeks of resistance training. J Strength Cond Res 2006;20:643-653.

7. Ballard T, Specker B, Binkley T, et al. Effect of protein supplementation during a 6-month strength and conditioning program on areal and volumetric bone parameters. Bone 2006;38:898-904.

8. Bemben MG, Witten MS, Carter DL, et al. The effects of supplementation with creatine and protein on muscle strength following a traditional resistance training program in middle-aged and older men. J Nutr Health Aging 2010;14: 155-159.

9. Campbell W, Crim M, Young V, et al. Effects of resistance training and dietary protein intake on protein metabolism in older adults. Am J Physiol Endocrinol Metab 1995;268:E1143-E1153.

10. Rozenek R, Ward P, Long S, et al. Effects of high-calorie supplements on body composition and muscular strength following resistance training. J Sports Med Phys Fitness 2002;42:340-347.

11. Verdijk L, Jonkers R, Gleeson B, et al. Protein supplementation before and after exercise does not further augment skeletal muscle hypertrophy after resistance training in elderly men. Am J Clin Nutr 2009;89:608-616.

12. Walberg Rankin J, Goldman L, Puglisi M, et al. Effect of postexercise supplement consumption on adaptations to resistance training. J Am Coll Nutr 2004; 23:322-330.

13. Cermak N, Res P, de Groot L, et al. Protein supplementation augments the skeletal muscle adaptive response to resistance-type exercise training: A metaanalysis. Am J Clin Nutr 2012;96:1454-1464.

14. Tieland $M$, Dirks ML, van der Zwaluw N, et al. Protein supplementation increases muscle mass gain during prolonged resistance-type exercise in frail eldelry people: A randomized double-blind, placebo-controlled trial. J Am Med Dir Assoc 2012;13:713-719.

15. Leenders M, Verdijk L, Hoeven L, et al. Protein supplementation during resistance-type exercise training in the elderly. Med Sci Sports Exerc; 2012. Sept 10 Epub ahead of print.

16. Peterson M, Sen A, Gordon P. Influence of resistance exercise on lean body mass in aging adults: A meta-analysis. Med Sci Sports Exerc 2011;43:249-258.

17. Tieland M, van de Rest O, Dirks ML, et al. Protein supplementation improves physical performance in frail elderly people: A randomized, double-blind, placebo-controlled trial. J Am Med Dir Assoc 2012;13:720-726.

Naomi M. Cermak, PhD

Department of Human Movement Sciences NUTRIM School for Nutrition, Toxicology and Metabolism Maastricht University Medical Centre ${ }^{+}$, Maastricht, The Netherlands

Lisette CPGM de Groot, MSc, PhD Division of Human Nutrition, Wageningen University, Wageningen, The Netherlands

Luc J.C. van Loon, PhD

Department of Human Movement Sciences, NUTRIM School for Nutrition, Toxicology and Metabolism, Maastricht University Medical Centre $^{+}$, Maastricht, The Netherlands

http://dx.doi.org/10.1016/j.jamda.2012.10.003

\section{Perspective: Protein Supplementation in Frail Older Persons: Often Necessary but Not Always Sufficient}

\section{To the Editor:}

Since 1838, when Gerardus Johannes Mulder first described proteins and used the name derived from the Greek word $\pi \rho \omega \tau \varepsilon \tilde{0} \widetilde{\zeta}$ (proteios), meaning "primary," the importance of proteins in human physiology has incessantly expanded. ${ }^{1}$ The demonstration that muscle contraction is the result of the interaction of 2 proteins with ATP signed the beginning of a new era in physiology. ${ }^{2}$ Because proteins are key nutrients for every cell in the human body, their role in the maintenance of cellular function during aging is unquestionable. The human body is unable to repair, regulate, and especially to move without these vital macronutrients. Essential amino acids cannot be synthesized in the body, whereas proteins are the only macronutrient without inactive reservoir, hence they might be taken with food. Even if skeletal muscle mass preservation during aging is influenced by multiple factors, ${ }^{3,4}$ the content of amino acids in the diet is a requisite for muscle protein synthesis. 5

Frailty and age-related sarcopenia are closely interconnected. Frail older persons are sarcopenic by definition, ${ }^{7}$ whereas advanced age-associated sarcopenia may lead to frailty, risk for falls, and loss of independence. ${ }^{8}$ However, other features characterize frailty together with the loss of muscle mass and function. The concept of frailty is so complex and heterogeneous that in the past decade, various interpretations of its notion have been proposed. These include, among others, a definition according to the presence of few biological and functional characteristics identifying a specific phenotype $^{9}$; a progressive accumulation of deficits (a scale of up to 70 items $^{10}$; an integrated approach including physical, psychological, and social domains ${ }^{11}$; and a multidimensional concept where multiple domains aggregate together and interact. ${ }^{12,13}$ Such a complex condition varies widely among populations and among individuals in the same population, hence it is not surprising that results from trials conducted in frail persons with extensive heterogeneity may not agree, even if a plausible intervention is examined, that is, protein supplementation in frail older persons, who are at high risk for undernutrition. ${ }^{14}$ Several studies have shown positive effects for such intervention, ${ }^{15-20}$ but there are also negative results. ${ }^{17,21}$ Moreover, even if protein deficiency or a blunted anabolic response to dietary nutrients could be overcome with a protein supplement, other mechanisms proposed as mediators of age-associated sarcopenia and frailty, such as mitochondrial dysfunction, ${ }^{22}$ calcium transport alterations, ${ }^{23}$ intramyocellular lipids, ${ }^{24}$ and/or inflammation ${ }^{25}$ may add to the uneven response to protein supplements. The presence of other deficits that may exacerbate sarcopenia and alter ATP availability, that is, vitamin $\mathrm{D}^{26}$ or magnesium, ${ }^{27}$ may also help to explain the lack of response in some frail persons to the added protein intervention, in addition to the variability in study design, dose, composition, and schedule of protein supplementation.

The role of physical inactivity in the genesis of sarcopenia and frailty is compelling, as shown consistently by studies demonstrating a rescue of muscle performance with resistance strength training. ${ }^{28}$ Thus, it is plausible that multi-intervention approaches, such as combining protein supplementation with resistance exercise training, ${ }^{15}$ among other integrated strategies, are necessary to overcome the muscle protein anabolic resistance associated with old age. ${ }^{29}$ Insulin resistance may affect protein synthesis, ${ }^{30}$ which can be ameliorated with physical exercise ${ }^{15,20,31}$ or other strategies. $^{32}$ Supplementing proteins without considering total caloric intake may be misleading, because a positive nitrogen balance to increase protein synthesis cannot occur if there is an energy deficit, which is frequently associated with frailty. ${ }^{33}$ Furthermore, a highprotein diet with a low or an inadequate caloric intake has a higher thermogenic effect and may induce satiety, ${ }^{34}$ which may worsen anorexia and undernutrition in a frail person.

Demonstrating a clear benefit of protein supplementation on frail persons may be challenging because of the many confounding factors involved. One single strategy may not be completely successful in the treatment of sarcopenia and frailty because of the complexity of the pathogenesis and symptoms of these syndromes. Thus, multicomponent interventions, such as those proposed in 
other geriatric strategies, ${ }^{35}$ might be implemented. Frail persons living in long term care facilities are often undernourished, hence protein supplementation as a regular practice seems to be indicated, but a single correction is probably not sufficient to impact general health, quality of life, or survival. Cost-effectiveness analysis issues may arise if protein supplements for frail persons would be universally implemented on a regular basis. Assessment of renal function, frequently compromised in frail older persons, is needed before a higher protein diet as part of a multi-intervention approach is initiated and in the course of the intervention, as well as a comprehensive geriatric assessment to help in the decision whether such intervention is most likely beneficial on an individual basis.

\section{References}

1. Perrett D. From 'protein' to the beginnings of clinical proteomics. Proteomics Clin Appl 2007;1:720-738.

2. Szent-Gyorgyi AG. The early history of the biochemistry of muscle contraction. J Gen Physiol 2004;123:631-641.

3. Narici MV, Maffulli N. Sarcopenia: Characteristics, mechanisms and functional significance. Br Med Bull 2010;95:139-159.

4. Morley JE. Anorexia, sarcopenia, and aging. Nutrition 2001;17:660-663.

5. Paddon-Jones D, Sheffield-Moore M, Zhang XJ, et al. Amino acid ingestion improves muscle protein synthesis in the young and elderly. Am J Physiol Endocrinol Metab 2004;286:E321-E328.

6. Volpi E, Kobayashi, Sheffield-Moore M, et al. Essential amino acids are primarily responsible for the amino acid stimulation of muscle protein anabolism in healthy elderly adults. Am J Clin Nutr 2003;78:250-258.

7. Morley JE. Frailty: Diagnosis and management. J Nutr Health Aging 2011;15: 667-670.

8. Morley JE, Abbatecola AM, Argiles JM, et al. Sarcopenia with limited mobility: An international consensus. J Am Med Dir Assoc 2011;12:403-409.

9. Fried LP, Tangen CM, Walston J, et al. Frailty in older adults: Evidence for a phenotype. J Gerontol A Biol Sci Med Sci 2001;56:M146-M156.

10. Rockwood K, Mitnitski A. Frailty in relation to the accumulation of deficits. J Gerontol A Biol Sci Med Sci 2007;62:722-727.

11. Gobbens RJ, Luijkx KG, Wijnen-Sponselee MT, Schols JM. In search of an integral conceptual definition of frailty: Opinions of experts. J Am Med Dir Assoc 2010;11:338-343.

12. Sourial $\mathrm{N}$, Wolfson $\mathrm{C}$, Bergman $\mathrm{H}$, et al. A correspondence analysis revealed frailty deficits aggregate and are multidimensional. J Clin Epidemiol 2010;63: 647-654.

13. Fulop T, Larbi A, Witkowski JM, et al. Aging, frailty and age-related diseases. Biogerontology 2010;11:547-563.

14. Morley JE. Undernutrition in older adults. Fam Pract 2012;29:i89-i93.

15. Tieland M, Dirks ML, van der Zwaluw N, et al. Protein supplementation increases muscle mass gain during prolonged resistance-type exercise training in frail elderly people: A randomized, double- blind, placebo-controlled trial. J Am Med Dir Assoc 2012;13:713-719.

16. Tieland M, van de Rest O, Dirks ML, et al. Protein supplementation improves physical performance in frail elderly people: A randomized, double-blind, placebo-controlled trial. J Am Med Dir Assoc 2012;13:720-726.

17. Milne AC, Potter J, Vivanti A, Avenell A. Protein and energy supplementation in elderly people at risk from malnutrition. Cochrane Database Syst Rev 2009;2: CD003288.

18. Chevalier S, Gougeon R, Nayar K, Morais JA. Frailty amplifies the effects of aging on protein metabolism: Role of protein intake. Am J Clin Nutr 2003;78:422-429.

19. Kim CO, Lee KR. Preventive effect of protein-energy supplementation on the functional decline of frail older adults with low socioeconomic status: A community-based randomized controlled study. J Gerontol A Biol Sci Med Sci; 2012 Aug 9 [Epub ahead of print].

20. Solerte SB, Gazzaruso C, Bonacasa R, et al. Nutritional supplements with oral amino acid mixtures increases whole-body lean mass and insulin sensitivity in elderly subjects with sarcopenia. Am J Cardiol 2008;101:69E-77E.

21. Baldwin C, Weekes CE. Dietary advice with or without oral nutritional supplements for disease-related malnutrition in adults. Cochrane Database Syst Rev 2011;9:CD002008.

22. Safdar A, Hamadeh MJ, Kaczor JJ, et al. Aberrant mitochondrial homeostasis in the skeletal muscle of sedentary older adults. PLoS One 2010;5:e10778.

23. Andersson DC, Betzenhauser MJ, Reiken S, et al. Ryanodine receptor oxidation causes intracellular calcium leak and muscle weakness in aging. Cell Metab 2011;14:196-207.

24. Nakagawa $Y$, Hattori $M$, Harada $K$, et al. Age-related changes in intramyocellular lipid in humans by in vivo H-MR spectroscopy. Gerontology 2007; 53:218-223.

25. Hubbard RE, Woodhouse KW. Frailty, inflammation and the elderly. Biogerontology 2010;11:635-641.

26. Morley JE, Argiles JM, Evans WJ, et al. Nutritional recommendations for the management of sarcopenia. J Am Med Dir Assoc 2010;11:391-396.
27. Dominguez LJ, Barbagallo $M$, Lauretani $F$, et al. Magnesium and muscle performance in older persons: The InCHIANTI study. Am J Clin Nutr 2006;84: 419-426.

28. Liu CJ, Latham NK. Progressive resistance strength training for improving physical function in older adults. Cochrane Database Syst Rev 2009;3:CD002759.

29. Drummond MJ, Dreyer HC, Pennings B, et al. Skeletal muscle protein anabolic response to resistance exercise and essential amino acids is delayed with aging. J Appl Physiol 2008;104:1452-1461.

30. Rasmussen BB, Fujita S, Wolfe RR, et al. Insulin resistance of muscle protein metabolism in aging. FASEB J 2006;20:768-769.

31. Timmerman KL, Dhanani S, Glynn EL, et al. A moderate acute increase in physical activity enhances nutritive flow and the muscle protein anabolic response to mixed nutrient intake in older adults. Am J Clin Nutr 2012;95:1403-1412.

32. Timmerman KL, Lee JL, Fujita S, et al. Pharmacological vasodilation improves insulin-stimulated muscle protein anabolism but not glucose utilization in older adults. Diabetes 2010;59:2764-2771.

33. Bartali B, Frongillo EA, Bandinelli $S$, et al. Low nutrient intake is an essential component of frailty in older persons. J Gerontol A Biol Sci Med Sci 2006;61: 589-593.

34. Halton TL, Hu FB. The effects of high protein diets on thermogenesis, satiety and weight loss: A critical review. J Am Coll Nutr 2004;23:373-385.

35. Tinetti ME, Brach JS. Translating the fall prevention recommendations into a covered service: Can it be done, and who should do it? Ann Intern Med 2012; 157:213-214.

Ligia J. Dominguez, MD

Mario Barbagallo, MD

Geriatric Unit, Department of Internal Medicine and Medical Specialties University of Palermo Palermo, Italy

http://dx.doi.org/10.1016/j.jamda.2012.09.029

\section{Perspective: Exercise and Protein Supplementation in Frail Elders}

\section{To the Editor:}

In the October 2012 issue of this journal, Michael Tieland and colleagues ${ }^{1,2}$ present two studies exploring longer duration protein supplementation in older adults. It is easy to be enthusiastic about these studies. The choice of study population (frail elders) is compelling, and the interventions (protein supplementation and exercise) are clinically and intuitively desirable. Dietary protein intake and physical activity are the key modifiable means of stimulating muscle protein anabolism. ${ }^{3-5}$ However, one of the lingering problems facing muscle metabolism researchers is the tenuous link between highly controlled, acute, mechanistic studies and longer duration, outcome-focused trials. ${ }^{6-8}$ In their articles, Tieland et al $^{1,2}$ clearly demonstrate that making the translational leap from a successful acute, mechanistic result to longer term improvement in outcomes such as muscle mass and function is possible but should not be an automatic expectation.

The two articles presented in the October issue use a traditional "protein supplementation/exercise training" experimental design: Expose volunteers to a resistance exercise or protein supplementation regimen, or both, for 24 weeks and closely monitor outcomes. ${ }^{1,2}$ However, instead of being formulaic, the authors have incorporated several novel design elements in their work. Notably, the investigators specifically target breakfast and lunch, two traditionally lower protein meals, as the times to provide protein supplementation. This represents a more thoughtful, meal-driven approach to protein supplementation, which aims to optimize muscle anabolism by delivering a moderate amount of high-quality protein at each meal, rather than dumping the bulk of the day's protein in a single meal. ${ }^{9,10}$ 